\title{
下顎智齒埋伏ニ因スル神經痛様疼痛
}

東京帝國大學醫學部䕎科學教室

加藤 清 利

\section{Ein Fall von retinierten Unterweissheitzahn mit}

neuralgieartigem Schmerz.

\author{
Von \\ Dr. K. Kato. \\ (Aus der zahärztlichen Klinik der Kaiserlichen Universität zu Tokio)
}

\section{緒 言}

顏面二於テ，三种經，分布領域二見ラル、神經痛站二神經痛樣疼痛八，甚ダシク 患者丹苦シメ, 時二其ノ診斷二苦シュ, 又治療二困難キ感ズルコトアリテ, 吾人臨林 家ニトリテ甚名興味アルモノ、ーナリト信ズ。顏面二於ケル疼痛發作八，大別シテ二 ットナスキ得ベク，一八眞ノ神經痛ニシテ神經系統ノ一疾患卜見做スベキモノ, 其二 八神經痛樣顏面疼痛發作ニシテ，其，症狀八全然第一ノモノニ等シキモ他ノ明二認 メ 得べキ全身站ビ二局所的疾患，䉆メ二第二次的二疼痛發作キ起 シ, 又特發性二惹起七 ラル、コトアリ。全身的疾患トシテハ 1）傳染性疾患「インフルエンザ」「「マラリ ア」，「チブス」，2）慢性疾患（徽毒，糖尿病，痛風） 3）中毒性疾患(鉛，水銀, 「二」 チン」，砒素，酒精） 4）血液病 5）子宮疾患 6）內分泌異常等ニョリテ來ル。

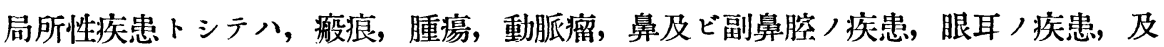
ビ吾々ガ日常診療ニ從事セル齒買口腔領域疾患ニヨリテ疼痛發作キ惹起セラル、コト

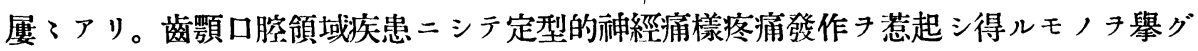

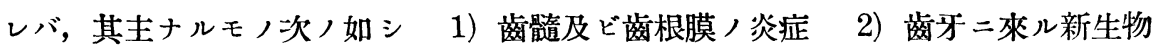 (A) 象牙質瘤
B）白忹質瘤
C）白㤠質肥大
D）第二次形成象牙質)
3) 跻系性 腫場 （A）齒根襄腫及ビ滤胞性齒牙囊腫

B）珐郎上皮腫

C）齒牙腫)

4）埋伏 萬

5）茼牙周圍，疾患 (A）齿性骨髓炎

B）顠骨，亞砒酸二ヨル壤誼

C) 齒槽

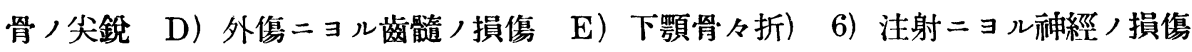

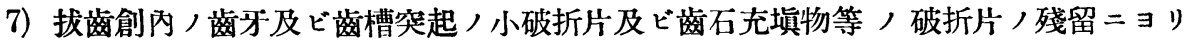
テ筐一次的二若圮セラル、モノナリ。余八最近左下顎智荀位置異常埋伏ニョリテ神經 
痛樣疼痛キ惹起七りト思ハル、一例キ得タルチモツテコ、二報告セントス。

\section{症 例}

患者 21 歲 우 會社員/娘。

家族歷 父方租父母健在，母方租父母共二死亡七り。父母健在，同胞 13 人队 4 人 死亡, (死因不明) 他八健在ナリ。

㖸往病歷 生來健康ニシテ著忠チ知ラズ。

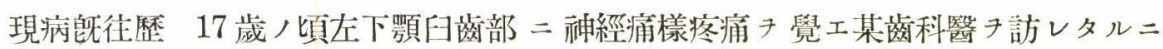

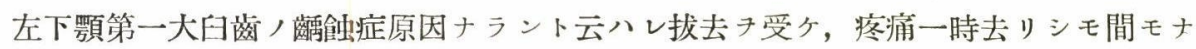
ク再ビ疹痛フ訴一同崡科醫タ訪レシガ原因不明ト云ハレソノ、、放置サル，其後漸時

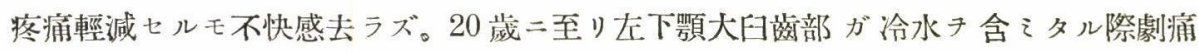

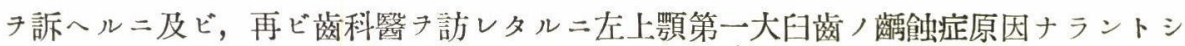
テ處置チ受ケタリシモ疼痛去ラズ加フルニ眼瞼口脣舌二知覺鈍麻チ覺エ殊二就蔣時左

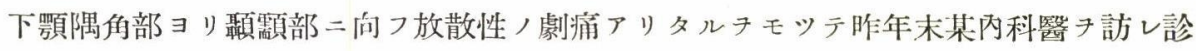
チ受ケタルモ少シモ快方二向ハヌ, ミカ, 頭痛及ビ睡眠不能ニシテ記憶力著シク減退 シ來タルチモツテ, 本年 1 月 8 日本學物療內科二診チ乞ヒタル二全身的二八異常丹認 メラレズトテ 1 月 13 日內科ヨリ當敎室外來患者診療所二紹介七ラレタルモノナリ。 現症 體格榮養中等度, 睡眠不能ナルタメカ顏貌著シク憔悴シタルモ脈搏呼吸何レ

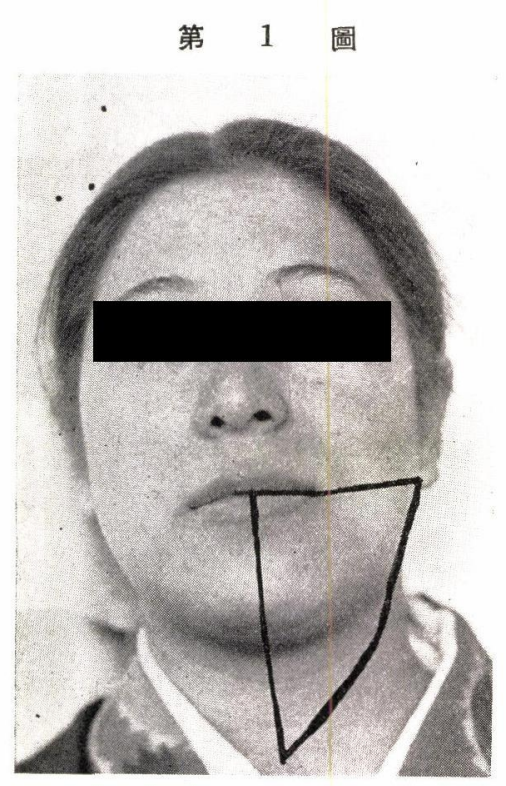
モ正常, 體溫 36 度 1 分其他全身的二異常子 認メズ，扁桃腺及ビ所屬淋巴腺二變化ナク， 眼瞼, 口序, 運動狀態及ビ咀纙運動正常ナ リ。左下頴部二於テハ視診上異常キ認メラレ ザルモ知覺著シク鈍麻ニシテ時々劇痛訴 フ。其, 頓部及ビ頸部, 皮膚二於ケル知覺鈍 麻, 部于檢スル二次, 如シ。上緣左側口角ヨ リ同側耳珠二到儿線, 前緣, 下序, 正中部 リ喉頭,下部二到ル正中線以上二線ヨ二櫋卜 七ル大體本行四櫋形ノ部分ナリ(第 1 圖參照) 口腔內子檢スル二比較的清掃狀態保タル，患 側願孔二當儿部分二稍了壓痛アルモ其他粘膜 部及齒栫部共二腫脹, 發赤, 壓痛, 自發痛

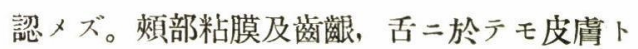


同程度ノ知覺鈍麻アリ。其ノ範圍ハ大體皮膚二於ケルモノニ相當シ後緣ハ智齒部二至 ル。齒牙チ檢スル二患者ノ訴へシ左下顎部ハ左下顎第一大田齒缺損シホダ智齒ノ萌出

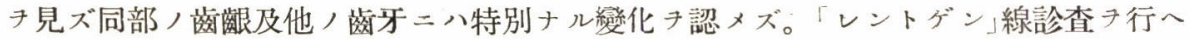
ル二左下顎第一大目齒缺損部八異常ナク智齒, 理伏キ認メ所謂水本智齒, 狀態キ呈シ

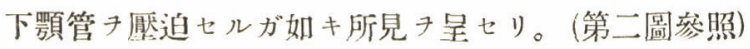

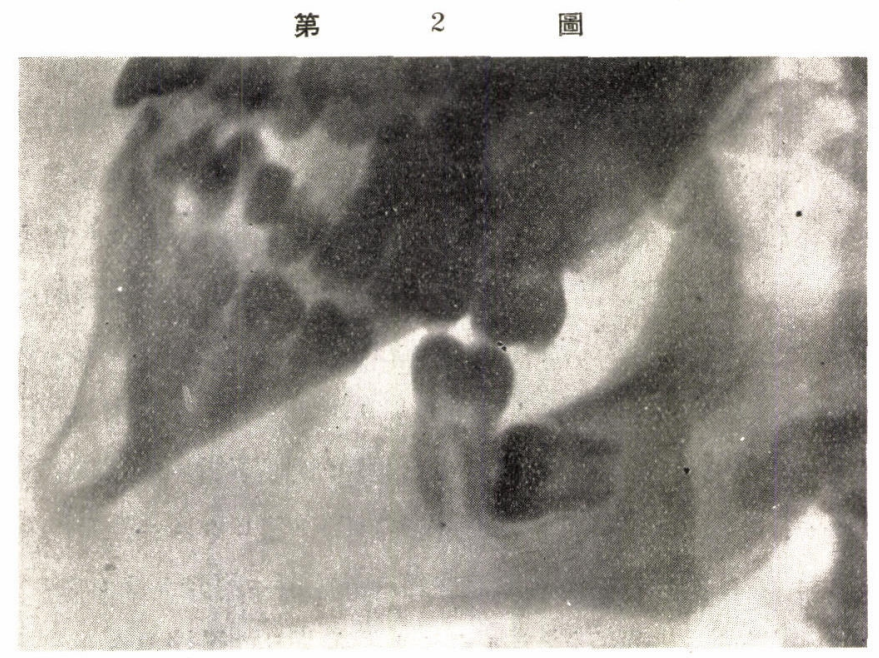

血液檢查所見 血色素 85 (nach Sahli) 赤血球數 (6992000) 白血球數 (7.800) 白血球數種類，百分率八中性嗜好多形核白血球 (71\%), 淋巴球 $(24 \%)$ 大單核細胞 ( 5 \%) 赤血球沈降速度 (ウエスターグレン氏法) 本均價 13.2 竓， ワ氏村田氏反應共二陰性 ナリ。

尿檢查所見 澄明ニシテ酸性, 比重 $(1025)$ 蛋白及糖き證明セズ。

診斷 以上/症狀二ヨリ左下顎智苳埋伏位置異常二因スル三仅神經痛樣顏面疼痛發 作トナスコト最モ穻當ナリ。

經過及處置 來院當時患者ハ疼痛發作持續的ナラザルモ患部ノ異常感及ビ連日連夜

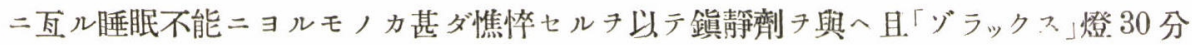
間照射 行へルニ經過頗ル良好ニシテ疼痛發作滅少シ比較的安眠チ得ラル、二至ルチ モツテ 1 月 24 日入院キ命ジ郎日金森钽授ニョリテ原因齒ト思ハル、智齒キ拔去セり。 其後經過良好ナルキモツテ 27 日退院外來通院キ命ジ拔齒創, 後處置キ行へル二創稘 治癒卜同時二全ク其ノ發作ノ後き斷チ患部ノ不快感モ全》消散セシムルチ得タリ。

總括及考按 由來埋伏齒八之ョ完全埋伏ト牛萌出狀態トノ二ッニ區別七ラル。完全 


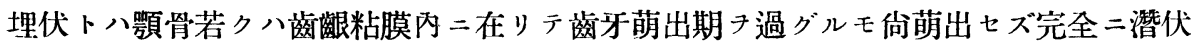
シ肉眼的二觀察シ得ザリシモノニシテ牛萌出狀態卜八字句ノ示ス如ク萌出期後齒牙， 一部分チ口腔内二露出シ完全ナル萌出キ七ザルモノキ稱ス。乳齒ニアリテハ埋伏セル

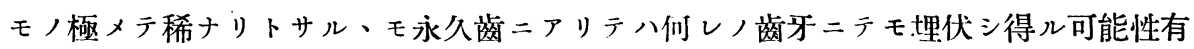
リ。埋伏齒牙發現頻度キ齒牙種別二分類スレバ上顎犬齒及ビ下顎智齒最高き占メ七顎 前齒之二次グ，埋伏齒，原因二關シテハ古クヨリ諸學者ニヨリテ議論セラレ其ノ原因 トシテ，1）顎骨，發育不全，2）齒芽，位置不正，3）齒芽ノ外㑺，4）萌出路，閉塞 5）遺傳，6）乳齒，晚期殘存，7）全身的疾患等擧ゲラル、モ未ダ一定セル學說ナシ。

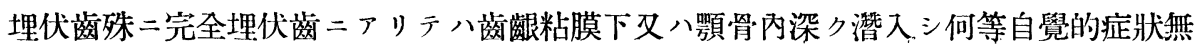
ク外觀上又異常キ認メラレズ一生涯キ通ジテ何等特別ナル障碍キ忿起七ズシテ經過ス ルコトアレ共時トシテ隣在齒二障碍チ及ボシ其ノ齒根, 吸收及ビ齒槽骨, 崩壞丹生シ

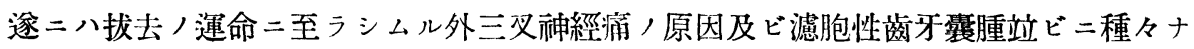
ル腫瘍ノ成立二關連スルコトアリ。下顎智齒埋伏八臨牀的二屢了遭遇セラル、モコレ 二反シテ三双神經痛テ惹起七リト思ハル、臨牀例甚名僅少ナリ。本症例ハ位置異常且 埋伏セル智齒二困り過去數年間二瓦り常二左下顎煩部ノ知覺異常不快感二惱マサレ時

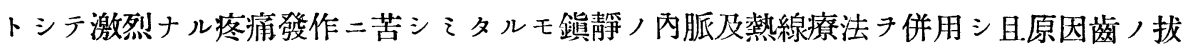
去ニヨリ直ニソノ症狀ノ消退セルモノニシテ斯ノ如キ場合二於テ診斷及ビ治療二際シ 「レントゲン」線診衒查最モ必要ニシテ且重要ナルコトハ言チ待タズ多年患者キ苦シメ タル神經痛樣疼痛ハ單ニ「レントゲン」線寫真像テ參照シタルノ ガ原因ナルコトチ察知シ得タル 1 例ナリ。

擱筆スルニ當り種々御指導キ賜リタル金森呚授二深謝ス。 